\title{
Mapping Quantitative Trait Loci Associated with Yield and its Related Traits in Sorghum bicolor
}

\author{
Alaa A Said ${ }^{(1)}$, Ralf Uptmoor ${ }^{(2)}$ and Mohamed El-Soda ${ }^{(3)}$ \\ (1) Agronomy Department, Faculty of Agriculture, Sohag University, Sohag, Egypt; \\ ${ }^{(2)}$ Department of Agronomy, University of Rostock, Rostock, Germany; (3)Department \\ of Genetics, Faculty of Agriculture, Cairo University, Giza, Cairo, 12613, Egypt.
}

\begin{abstract}
$\mathbf{Y}$
IELD and its related traits; heading date, hundred kernel weight and kernels number as well as harvest index and biological yield are complex traits that require the concerted action of many genes and are affected by environmental cues. To genetically dissect those traits, 140 recombinant inbred lines (RILs) genotyped with 120 DArT and SSR markers were grown under field conditions in the two consecutive growing seasons 2015/2016 and 2016/2017 in Sohag, Egypt. A part from KN and HI, our results did show significant interaction between genotypes and the growing seasons $(\mathrm{GxS})$. The observed $\mathrm{GxS}$ was reflected by an interaction between the significant quantitative trait loci (QTL) and the growing seasons (QTLxS). In total, we report 13 significant QTL associated with HD, KW, SN, HI, and YLD, of which four QTL showed conditional neutrality as they were significant only in the second season. We observed significant negative correlation between HD and SN, HKW and YLD suggesting that selecting for early heading RILs with long grain filling period would increase the total yield, an observation that could be genetically dissected by the QTL cluster on LG-6. The associated markers mapped here can be used in breeding programs to select for favorable adaptive mechanisms, which is very crucial to meet the food requirement of an increasing human population.
\end{abstract}

Keywords: Sorghum biocolor, QTL mapping, Yield.

\section{Introduction}

Sorghum bicolor is a C4 grain crop and a main food and fodder resource. Sorghum, ranked the fifth most important grain crop worldwide after rice, wheat, maize and barley, is native to tropical and subtropical environments (Duodu et al., 2003; Xin et al., 2008 and Liu et al., 2014). Due to its genetic and physiological diversity, sorghum was domesticated in sub-Saharan Africa and southern Asia (Morris et al., 2013; Borrell et al., 2014 and Boyles et al., 2017). Sorghum hybrids can yield up to $10,000 \mathrm{~kg} \mathrm{ha}^{-1}$ when grown under ideal conditions (Jordan et al., 2012). The effect that each yield related traits has on total grain yield depends on the genotype $(\mathrm{G})$, environmental conditions throughout the growing season $(\mathrm{S})$ and their interaction, i.e. genotype-by-season (GxS) interaction (Chapman et al., 2000; El-Soda et al., 2014 and Boyles et al., 2017). Unravelling the genetic components underlying the observed $\mathrm{G} \times \mathrm{S}$ can be achieved via mapping quantitative traits loci (QTL) and their effects in different seasons, expressed as QTL-by-season interactions $(\mathrm{Q} \times \mathrm{S})$.
Since a high yield stability is a major breeding goal, this in turn would help exploiting sorghum genetic diversity for crop breeding programs and allow marker-assisted selection to select sorghum suitable for specific environments (Malosetti et al., 2004; Boer et al., 2007 and El-Soda et al., 2014).

Yield is a highly quantitative and complex trait and several studies mapped quantitative traits loci (QTL) associated with yield and its components (Rami et al., 1998; Brown et al., 2006; Srinivas et al., 2009; El Mannai et al., 2012; Rajkumar et al., 2013; Liu et al., 2014 and Boyles et al., 2017). Observing the allelic effect of each significant QTL facilitates mapping main effect QTL, i.e. the same allele can have equal effects on the same trait in two environments/seasons. On the contrary, a QTL can have unequal effects, i.e. being expressed strongly in one environment/ season but weakly in another environment/season. Additionally, a QTL can have a conditional neutrality effect, i.e. the QTL shows an effect on a trait in one environment/season but has no

Corresponding author email: alaa.said@agr.sohag.edu.eg

DOI: 10.21608/agro.2018.5431.1113

C2018 National Information and Documentation Center (NIDOC) 
effect on the same trait in another environment/ season. Finally, a QTL might have a antagonistic pleiotropic effect, which means that the same allele increase one yield component trait while it has a negative effect on another yield component (Malosetti et al., 2007 and El-Soda et al., 2014).

In the present study, we focused on investigating the genetic components underlying sorghum yield and its components. To achieve this goal, we grew140 recombinant inbred lines (RIL) genotyped with 120 DArT and SSR markers over two growing seasons in Sohag, Egypt.

\section{Materials and Methods}

\section{Plant material and experimental setup}

A recombinant inbred lines (RILs) population comprising $140 \mathrm{~F}_{4}$ RILs (Phuong et al., 2018) was used for the experiments. The population was derived from a cross between a high yielding parent (HYP) with superior grain quality and a drought tolerant parent (DTP) with intermediate yielding abilities. From the $\mathrm{F}_{1}, 140$ RILs were advanced to $\mathrm{F}_{4}$ by selfing and genotyped with 120 polymorghic markers, i.e. 112 DArTs and 8 SSRs markers, distributed over 14 linkage groups (LGs) that correspond to the 10 chromosomes (Phuong et al., 2018).

Two field experiments using the two parents and 140 RILs were carried out at the Experimental Farm of the Faculty of Agriculture, Sohag University, Egypt, in the two consecutive growing seasons 2015/16 and 2016/17. The experiments were designed in a randomized complete block design with two replications. The experimental plot consisted of two rows with two meters in length and $20 \mathrm{~cm}$ between rows. Plants were individually spaced at $10 \mathrm{~cm}$ within each row. At harvesting, 10 plants from each experimental plot were randomly chosen. Heading date (HD) for each RIL was measured as number of days from sowing date until $50 \%$ of each plot was blooming. Hundred kernel weight (HKW), kernels number $(\mathrm{KN})$, harvest index $(\mathrm{HI})$, biological yield (Bio) and yield (YLD) were scored for each genotype.

\section{Statistical and QTL analysis}

Two-way ANOVA was performed with the Statistical Analysis System SAS (SAS Institute, ver. 9.2 2002) using a general linear model to check for genotype, season and GxS interaction effects. Broad-sense heritability was calculated for each trait as the ratio between the genetic variance $\mathrm{Vg}$, i.e. the variance between the averages of all lines and the total phenotypic variance $\mathrm{Vt}$, where $\mathrm{Vt}=\mathrm{Vg}$ + the environmental variance, $V e$, i.e. the variance between replications of all lines. For QTL mapping, multiple QTL model (MQM) was applied using the statistical program $\mathrm{R}$ (version 3.4.1)following the procedure of Joosen et al. (2012).After removing outliers using $\mathrm{Z}$ transformation ( $\mathrm{Z}$-score $>3$ ), abasic linear model was fitted on the data from both seasons separately followed by acombined mapping to map the interaction between genotypes and seasons. LOD scores were calculated by taking the $-\log P$ values and based on 1000 permutations for the combined mapping of both seasons. LOD 2.5 was set as the significance threshold, however, QTL with thresholds lower than 2.5 are indicated as putative QTL in case they collocate with significant QTL for the same traits. Effects were calculated for all traits per year.

\section{$\underline{\text { Results }}$}

\section{RIL phenotyping}

Mean trait values of the parental lines high yielding parent and drought tolerant parent and the 140 RILs are shown in Table 1. High yielding parent had higher values than drought tolerant parent for all measured traits in the two growing seasons. The RIL population showed transgressive segregation beyond both parents for all traits over the two growing seasons. Heritability ranged between 0.63 to 0.97 . ANOVA showed significant differences between RILs for all traits. In case of the seasons, all traits except HI showed significant differences between both seasons. ANOVA showed significant GxS interaction for all traits except KN and HI. Average values of the 140 RILs in both seasons were compared using the revised least significant differences (RLSD) (Gomez \& Gomez, 1984) and data is available as supplementary file (S1).

The correlation analysis (Table 2) revealed positive significant correlations between the same traits; HKW, KN, BIO and YLD comparing both growing seasons. HD was always significantly negatively correlated with the rest of traits in both seasons. The other five traits were significantly positively correlated with each other. Only HI and Bio were not correlated in the two growing seasons. 
TABLE 1. Mean data of the parental lines and the RILs for the analyzed traits 2015/16 and 2016/17 growing seasons.

\begin{tabular}{|c|c|c|c|c|c|c|c|c|c|c|c|}
\hline \multirow{3}{*}{$\begin{array}{l}\text { Trait } \\
\text { season } \\
2016 / 17\end{array}$} & \multirow{3}{*}{ Unit } & \multirow{2}{*}{\multicolumn{2}{|c|}{ Parental lines }} & \multicolumn{8}{|c|}{ RIL population } \\
\hline & & & & \multirow{2}{*}{ Minimum } & \multirow{2}{*}{ Maximum } & \multirow{2}{*}{ Mean } & \multirow{2}{*}{ Std } & \multirow{2}{*}{$\mathbf{H}^{2}$} & \multicolumn{3}{|c|}{ ANOVA } \\
\hline & & HYP & DTP & & & & & & $\mathbf{G}$ & $\mathbf{S}$ & GxS \\
\hline HD16 & \multirow{2}{*}{ days } & 69.00 & 66.00 & 45.00 & 77.00 & 58.08 & 7.30 & 0.96 & \multirow{2}{*}{0.00} & \multirow{2}{*}{0.00} & \multirow[b]{2}{*}{0.00} \\
\hline HD17 & & 70.00 & 67.50 & 49.00 & 81.50 & 62.87 & 7.41 & 0.97 & & & \\
\hline HKW16 & \multirow{2}{*}{$\mathrm{g}$} & 2.81 & 2.18 & 0.50 & 3.00 & 1.63 & 0.58 & 0.70 & \multirow{2}{*}{0.00} & \multirow{2}{*}{0.00} & \multirow{2}{*}{0.01} \\
\hline HKW17 & & 3.23 & 2.84 & 0.61 & 3.84 & 2.12 & 0.83 & 0.76 & & & \\
\hline KN16 & & 892.00 & 777.00 & 91.80 & 1245.82 & 622.51 & 259.34 & 0.95 & \multirow{2}{*}{0.00} & \multirow{2}{*}{0.00} & \multirow{2}{*}{0.28} \\
\hline KN17 & & 1017.00 & 909.00 & 118.92 & 1647.80 & 759.57 & 315.64 & 0.94 & & & \\
\hline HI16 & & 17.57 & 18.63 & 5.10 & 56.59 & 22.11 & 11.46 & 0.63 & \multirow{2}{*}{0.00} & \multirow{2}{*}{0.87} & \multirow{2}{*}{1.00} \\
\hline HI17 & & 18.31 & 16.41 & 3.93 & 54.73 & 21.96 & 10.97 & 0.74 & & & \\
\hline BIO16 & \multirow{2}{*}{$\mathrm{g}$} & 202.49 & 150.07 & 32.25 & 197.48 & 88.71 & 29.88 & 0.73 & \multirow{2}{*}{0.00} & \multirow{2}{*}{0.00} & \multirow{2}{*}{0.00} \\
\hline $\mathrm{BIO} 17$ & & 249.78 & 204.96 & 43.90 & 280.15 & 123.36 & 43.97 & 0.88 & & & \\
\hline YLD16 & \multirow{2}{*}{ g plant $^{1}$} & 35.58 & 27.95 & 2.82 & 56.58 & 18.90 & 11.85 & 0.74 & \multirow{2}{*}{0.00} & \multirow{2}{*}{0.00} & \multirow{2}{*}{0.01} \\
\hline YLD17 & & 45.73 & 33.64 & 3.92 & 71.20 & 26.63 & 15.92 & 0.77 & & & \\
\hline
\end{tabular}

$-\mathrm{HD}=$ Heading date, $\mathrm{HKW}=100$ kernel weight, $\mathrm{KN}=$ Kernels number per plant, $\mathrm{HI}=$ Harvest index, $\mathrm{BIO}=\mathrm{Biological}$ yield, $\mathrm{YLD}=\mathrm{Y}$ ield. $-\mathrm{H}^{2}$ refers to heritability; G, S and GxS refers to genotype, season and their interaction, respectively.

-Following trait abbreviations refer to the growing season.

TABLE 2. Correlation coefficients between the analyzed traits in both growing season.

\begin{tabular}{|c|c|c|c|c|c|c|c|c|c|c|c|}
\hline & HD16 & HKW16 & KN16 & HI16 & BIO16 & YLD16 & HD17 & HKW17 & KN17 & HI17 & BIO17 \\
\hline HKW16 & $-0.567^{* *}$ & & & & & & & & & & \\
\hline KN16 & $-0.345^{* *}$ & $0.256^{* *}$ & & & & & & & & & \\
\hline HI16 & $-0.366^{* *}$ & $0.370^{* *}$ & $0.739^{* *}$ & & & & & & & & \\
\hline BIO16 & $-0.338^{* *}$ & $0.575^{* *}$ & $0.276^{* *}$ & -0.009 & & & & & & & \\
\hline YLD16 & $-0.445^{* *}$ & $0.593^{* *}$ & $0.770^{* *}$ & $0.756^{* *}$ & $0.575^{* *}$ & & & & & & \\
\hline HD17 & $0.973^{* *}$ & $-0.572^{* *}$ & $-0.348^{* *}$ & $-0.367^{* *}$ & $-0.362^{* *}$ & $-0.453^{* *}$ & & & & & \\
\hline HKW17 & $-0.658^{* *}$ & $0.885^{* *}$ & $0.345^{* *}$ & $0.418^{* *}$ & $0.574^{* *}$ & $0.664^{* *}$ & $-0.661 * *$ & & & & \\
\hline KN17 & $-0.334^{* *}$ & $0.225^{* *}$ & $0.961^{* *}$ & $0.686^{* *}$ & $0.257^{* *}$ & $0.723^{* *}$ & $-0.331^{* *}$ & $0.328 * *$ & & & \\
\hline HI17 & $-0.364 * *$ & $0.334^{* *}$ & $0.710^{* *}$ & $0.871^{* *}$ & 0.043 & $0.759^{* *}$ & $-0.347^{* *}$ & $0.409 * *$ & $0.667^{* *}$ & & \\
\hline BIO17 & $-0.390^{* *}$ & $0.601^{* *}$ & $0.293^{* *}$ & 0.084 & $0.890^{* *}$ & $0.548^{* *}$ & $-0.418^{* *}$ & $0.593^{* *}$ & $0.273^{* *}$ & -0.035 & \\
\hline YLD17 & $-0.480^{* *}$ & $0.615^{* *}$ & $0.755^{* *}$ & $0.717^{* *}$ & $0.596^{* *}$ & $0.980^{* *}$ & $-0.484^{* *}$ & $0.679^{* *}$ & $0.707^{* *}$ & $0.770^{* *}$ & $0.566^{* *}$ \\
\hline
\end{tabular}

$-\mathrm{HD}=$ Heading date, $\mathrm{HKW}=100$ kernel weight, $\mathrm{KN}=$ Kernels number per plant, $\mathrm{HI}=$ Harvest index, $\mathrm{BIO}=\mathrm{Biological}$ yield, $\mathrm{YLD}=\mathrm{Yield}$. -Correlations between traits are statistically significant at the $0.05\left(^{*}\right)$ and $0.01\left({ }^{* *}\right)$ probability level. 


\section{QTL mapping}

Total of 13 showed significant QTL were mapped for HD, HKW, KN, HI and YLD (Table 3 and Fig. 1). Four QTL, i.e. KW1, HI1, YLD2 and YLD5, mapped on LGs 3, 2a, 4 and 9a, respectively, showed conditional neutrality since they were significant only in the second season. Three main effects QTL, i.e HD1, HD2, HI2 were mapped to LGs $2 \mathrm{a}$ and 6 as they showed same effects in both growing seasons.
Total of 5 significant epistatic interactions between significant markers were observed for $\mathrm{KN}$ in the first and YLD in the second growing seasons (Fig. 2). In case of KN, the epistasis was observed between spbn-6724 on LG-2 and spbn3738 on LG-6. For YLD, two epistatic interactions were observed between spbn-0854 and both of spbn-7660 on LG-6 and spbn-6414 on LG-9a. An additional epistasis was observed between spbn6855 on LG-5 and spbn-6414 on LG-9a.

TABLE 3. QTL mapped in the HYPXDTP recombinant inbred line population.

\begin{tabular}{|c|c|c|c|c|c|c|c|c|}
\hline \multirow{2}{*}{ Trait } & \multirow{2}{*}{$\begin{array}{l}\text { QTL_- } \\
\text { name }\end{array}$} & \multirow{2}{*}{ LG } & \multirow{2}{*}{$\begin{array}{l}\text { Significant } \\
\text { marker }\end{array}$} & \multirow{2}{*}{$\begin{array}{c}\text { Peak position } \\
\text { cM }\end{array}$} & \multicolumn{2}{|c|}{2016} & \multicolumn{2}{|c|}{2017} \\
\hline & & & & & LOD & Effect & LOD & Effect \\
\hline & HD1 & $2 \mathrm{a}$ & sPbn-2229 & 0 & 2.37 & -2.048 & 2.64 & -2.16 \\
\hline \multicolumn{9}{|l|}{ HD } \\
\hline & HD2 & 6 & sPbn-7660 & 9.5 & 6.61 & 3.031 & 6.61 & 3.02 \\
\hline & KW1 & 3 & sPbn-5454 & 22.2 & 1.09 & -0.088 & 2.64 & -0.21 \\
\hline \multicolumn{9}{|l|}{ KW } \\
\hline & KW2 & 6 & sPbn-7660 & 9.5 & 3.14 & -0.17 & 4.20 & -0.27 \\
\hline & KN1 & 2 & sPbn-6724 & 53.2 & 2.33 & 65.44 & 2.53 & 80.25 \\
\hline \multicolumn{9}{|l|}{$\mathrm{KN}$} \\
\hline & $\mathrm{KN} 2$ & 6 & sPbn-3837 & 38.3 & 3.98 & -77.44 & 3.90 & -94.21 \\
\hline & HI1 & $2 \mathrm{a}$ & sPbn-2229 & 0 & 0.83 & 2.22 & 2.58 & 3.26 \\
\hline \multicolumn{9}{|l|}{ HI } \\
\hline & HI2 & 6 & sPbn-7660 & 9.5 & 4.89 & -3.52 & 4.30 & -3.25 \\
\hline & YLD1 & 3 & sPbn-5454 & 22.2 & 2.56 & -2.88 & 2.22 & -3.67 \\
\hline & YLD2 & 4 & sPbn-0854 & 41.9 & 0.55 & 0.075 & 2.96 & 0.34 \\
\hline \multirow[t]{3}{*}{ Yield } & YLD3 & 5 & sPbn-6855 & 118.5 & 2.05 & 2.09 & 3.42 & 2.89 \\
\hline & YLD4 & 6 & sPbn-7660 & 9.5 & 5.91 & -2.89 & 5.77 & -4.51 \\
\hline & YLD5 & $9 \mathrm{a}$ & sPbn-6414 & 19.4 & 1.31 & 2.65 & 2.42 & 3.71 \\
\hline
\end{tabular}

$-\mathrm{LG}=$ Linkage group.

-Effects with positive values represent a positive contribution of the DTP allele to the trait value and with negative values represent a positive contribution of the HYP allele to the trait value.

$-\mathrm{HD}=$ Heading date, $\mathrm{HKW}=100$ kernel weight, $\mathrm{KN}=$ Kernels number per plant, $\mathrm{HI}=$ Harvest index, $\mathrm{BIO}=\mathrm{Biological}$ yield, $\mathrm{YLD}=\mathrm{Yield}$. -QTLs with LOD score less than 2.5 are presented as putative QTL and highlighted values indicate non-significant QTL. 


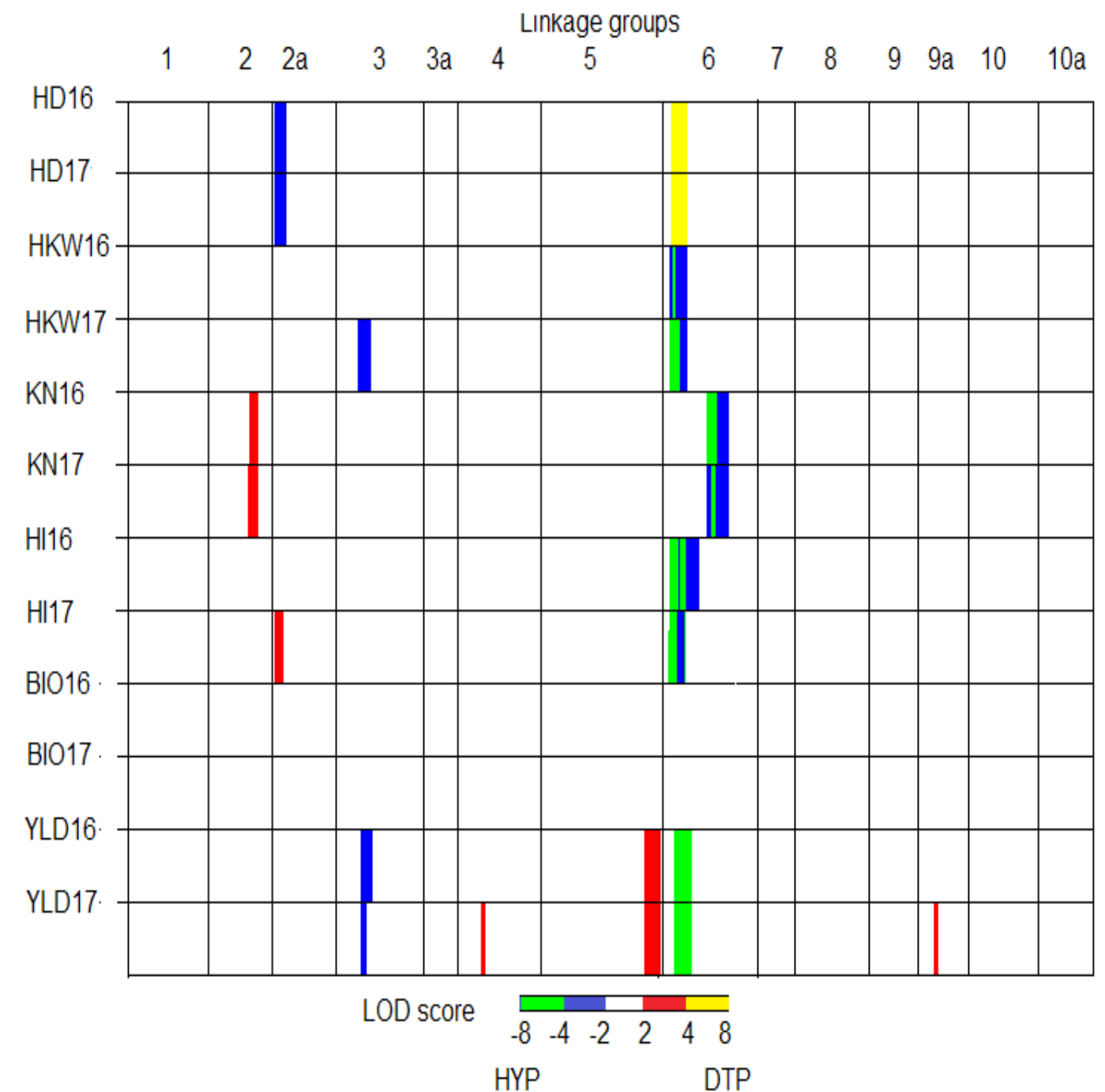

Fig .1. Heat map for the QTL mapped on 14 linkage groups (Columns show positions of main effect QTL across all traitseasons combinations and colors display the $-\log 10 \mathrm{P}$ value. Yellow and red indicate a significant positive effect from the DTP allele and green and blue indicate significant positive effects from the HYP allele in the given trait-environment combination. Numbers 16 and 17 refer to the growing seasons of the two experiments. $\mathrm{HD}=$ heading date, HKW= 100 kernel weights, $\mathrm{KN}=$ Kernels number, $\mathrm{HI}=$ Harvest index, $\mathrm{YLD}=$ Yield).

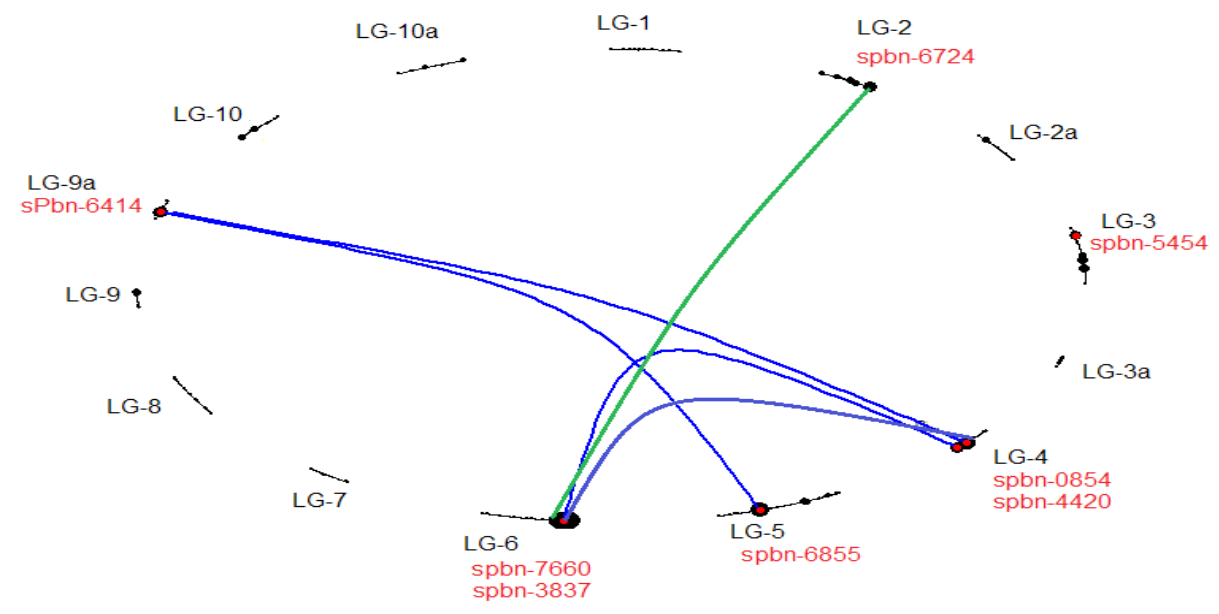

Fig. 2. Circle plot showing epistatic interactions between significant QTLs for seed number measured in the first growing season (green line) and for yield measured in the second growing season (blue lines). 


\section{Discussion}

Observing the performance of both parents in both growing seasons, i.e. in 2015/16 and in 2016/17, under natural field conditions showed that the high yielding parent gave higher hundred kernels weight, kernels number and yield than the drought tolerant parent. In case of HD which is negatively correlated with $\mathrm{HKW}, \mathrm{KN}$ and YLD, the DTP was earlier than the HYP. These observations are similar to their performance in the normal watering regime under greenhouse conditions (Phuong et al., 2018).

Results showed significant positive correlations between the same traits; HKW, KN, $\mathrm{BIO}$ and YLD comparing both growing seasons. This correlation was reflected in mapping several main effect quantitative trait loci (QTL) associated with most of the traits. For example, HD1 and HD2 were mapped in both growing seasons to the top of LG $2 \mathrm{a}$ and LG 6 , respectively. Three additional QTL, i.e. KW2, HI and YLD4, with positive effect from the HYP allele, were mapped in both growing seasons to the top of LG 6 colocating with HD2, with positive allelic effect from the early parent DTP. This co-location suggests favorable pleiotropic effects between $\mathrm{HD}$ and its three negatively correlated traits $\mathrm{KW}, \mathrm{KN}$ and YLD, where selecting for early heading RILs with long grain filling period would increase $\mathrm{KW}, \mathrm{KN}$ and the total yield. In general, it is very crucial to consider favorable as well as antagonistic pleiotropic effects while selecting for the desirable QTL during marker-assisted breeding programs. This is because selecting for the desirable allele underlying the desirable QTL for one trait might imply negative effects on other traits, in case of the antagonistic pleiotropic effects (Rose, 1982 and Juenger, 2013). Altogether, our observations mean that selecting for high yielding RILs with high KW would indirectly select for early heading RILs, three desirable traits, which is similar to the earlier observations in the same population (Phuong et al., 2018). Quantitative trait loci (QTL) for yield and its related traits on LG 6 co-locates with four QTL associated with yield and its component (Reddy et al., 2014).

The co-localization hotspot on top of LG 6 represents a putative regulatory QTL involved in maintaining general sorghum vigor under field conditions. Earlier studies reported that the same region to have pleiotropic effects as it was underlying ergot resistance (Parh et al., 2008), drought tolerance (Phuong et al., 2018), low temperature condition (Bekele et al., 2014), early seedling vigor (Rajkumar et al., 2013) and sugar related traits (Murray et al., 2008 and Shiringani et al., 2010). In addition, a QTL cluster associated with several agronomictraits under contrasting photoperiod conditions was also mapped to Chr6 using a sequencing-based mapping approach (Zou et al., 2012). Altogether, these results make the locus on top of LG 6 an interesting focus for studies on selection and fitness during sorghum evolution and may indicate a general role of this locus in sorghum growth and development under various environmental conditions.

Comparing our results with previously mapped QTL revealed co-location between HD1, SN1, and YLD3 with QTL mapped previously for the same traits in the same population (Phuong et al., 2018). However, the two QTL YLD1 and YLD2 were not mapped in the same study (Phuong et al., 2018) that used the same population. Both QTL might be associated with YLD measured in the field. The YLD3 QTL was mapped in a region carrying QTL for number of primary branches per panicle, a trait related to final yield, on SBI-05 (Reddy et al., 2014). To our knowledge, the two QTL associated with HI were not reported before.

ANOVA results showed significant $\mathrm{GxS}$ for KW and YLD which was reflected by significant QTLxS interactions. For example, conditional neutrality in case of KW1, YLD2 and YLD5. Results observed epistasis-by-season interactionsas the marker sPbn-7660 associated with YLD4 on LG 6, showed an epistatic interaction with the marker sPbn-0854 associated with YLD2 on LG 4 in case of the YLD measured in the second season. Additional epistasis observed in the second season only was observed between sPbn-0854, associated with YLD and sPbn-6414, associated with YLD5; an observation that might explain the conditional neutrality observed for YLD2 and YLD5.

In total, we mapped 13 significant QTL associated with the measured traits to understanding crop productivity under field conditions which is very crucial to meet the increasing human population. Mapping QTL underlying favorable responses as well as main effect QTL facilitates selecting the associated markers in the breeding programs. The current 
work presents the first step towards identifying genes underlying yield and its related traits.

Acknowledgment: The authors would like to thank the farmers at Faculty of Agriculture, Sohag University, Egypt for their efforts growing and harvesting the field experiments.

\section{$\underline{\text { References }}$}

Bekele, W.A., Fiedler, K., Shiringani, A., Schnaubelt, D., Windpassinger, S., Uptmoor, R., Friedt, W. and Snowdon, R.J. (2014) Unravelling the genetic complexity of sorghum seedling development under low-temperature conditions. Plant Cell Environ. 37. doi: $10.1111 /$ pce. 12189

Boer, M.P., Wright, D., Feng, L., Podlich, D.W., Luo, L., Cooper, M. and van Eeuwijk, F.A. (2007) A mixed-model quantitative trait loci (QTL) analysis for multiple-environment trial data using environmental covariables for QTLby-environment interactions, with an example in Maize. Genetics, 177, 1801-1813. doi:10.1534/ genetics.107.071068

Borrell, A.K., van Oosterom, E.J., Mullet, J.E., GeorgeJaeggli, B., Jordan, D.R., Klein, P.E. and Hammer, G.L. (2014) Stay-green alleles individually enhance grain yield in sorghum under drought by modifying canopy development and water uptake patterns. The New Phytologist, 203, 817-830. doi:10.1111/ nph.12869

Boyles, R.E., Pfieffer, B.K., Cooper, E.A., Zielinski, K.J., Myers, M.T., Rooney, W.L. and Kresovich, S. (2017) Quantitative trait loci mapping of agronomic and yield traits in two grain sorghum biparental families. Crop Science, 57, 2443-2456. doi:10.2135/cropsci2016.12.0988

Brown, P.J., Klein, P.E., Bortiri, E., Acharya, C.B., Rooney, W.L. and Kresovich, S. (2006) Inheritance of inflorescence architecture in sorghum TAG. Theoretical and Applied Genetics, 113, 931-942. doi:10.1007/s00122-006-0352-9

Chapman, S.C., Cooper, M., Butler, D.G. and Henzell, R.G. (2000) Genotype by environment interactions affecting grain sorghum. I. Characteristics that confound interpretation of hybrid yield. Australian Journal of Agricultural Research, 51, 197-208. doi:https://doi.org/10.1071/AR99020
Duodu, K.G., Taylor, J.R.N., Belton, P.S. and Hamaker, B.R. (2003) Factors affecting sorghum protein digestibility. Journal of Cereal Science, 38117-131. doi:https://doi.org/10.1016/S07335210(03)00016-X

El-Soda, M., Malosetti, M., Zwaan, B.J., Koornneef, M. and Aarts, M.G. (2014) Genotype x environment interaction QTL mapping in plants: Lessons from arabidopsis trends. Plant Science, 9, 390-398. doi:10.1016/j.tplants.2014.01.001

El Mannai, Y., Shehzad, T. and Okuno, K. (2012) Mapping of QTLs underlying flowering time in sorghum (Sorghum bicolor (L.) Moench). Breeding Science, 62,151-159. doi:10.1270/jsbbs.62.151

Gomez, K.A. and Gomez, A.A. (1984) "Statistical Procedures for Agricultural Research", $2^{\text {nd }}$ ed. John Wiley and Sons, NewYork, 680p.

Joosen, R.V.L., Arends, D., Willems, L.A.J., Ligterink, W., Jansen, R.C. and Hilhorst, H.W.M. (2012) Visualizing the genetic landscape of arabidopsis seed performance. Plant Physiology, 158, 570-589. doi:10.1104/pp.111.186676

Jordan, D.R., Hunt, C.H., Cruickshank, A.W., Borrell, A.K. and Henzell, R.G. (2012) The relationship between the stay-green trait and grain yield in elite sorghum hybrids grown in a range of environments. Crop Science, 52, 1153-1161. doi:10.2135/cropsci 2011.06 .0326

Juenger, T.E. (2013) Natural variation and genetic constraints on drought tolerance. Current OpinionPlant Biology, 16, 274-281. doi:http:// dx.doi.org/10.1016/j.pbi.2013.02.001

Liu, Q., Liu, H., Wen, J. and Peterson, P.M. (2014) Infrageneric phylogeny and temporal divergence of sorghum (andropogoneae, poaceae) based on lowcopy nuclear and plastid sequences. PLoS ONE, 9, e104933. doi:10.1371/journal.pone.0104933

Malosetti, M., Voltas, J., Romagosa, I., Ullrich, S.E. and van Eeuwijk, F.A. (2004) Mixed models including environmental covariables for studying QTL by environment interaction. Euphytica, 137, 139-145. doi:Doi 10.1023/B:Euph.0000040511.46388.Ef

Malosetti, M., Ribaut, J.M., Vargas, M., Crossa, J. and Eeuwijk, F.A. (2007) A multi-trait multienvironment QTL mixed model with an application 
to drought and nitrogen stress trials in maize (Zea mays L.). Euphytica, 161, 241-257. doi:10.1007/ s10681-007-9594-0

Morris, G.P., Ramu, P., Deshpande, S.P., Hash, C.T., Shah, T., Upadhyaya, H.D., Riera-Lizarazu, O., Brown, P.J., Acharya, C.B., Mitchell, S.E., Harriman, J., Glaubitz, J.C., Buckler, E.S. and Kresovich, S. (2013) Population genomic and genome-wide association studies of agroclimatic traits in sorghum. Proceedings of the National Academy of Sciences, 110, 453-458. doi:10.1073/ pnas. 1215985110

Murray, S.C., Sharma, A., Rooney, W.L., Klein, P.E., Mullet, J.E., Mitchell, S.E. and Kresovich, S. (2008) Genetic improvement of sorghum as a biofuel feedstock: I. QTL for stem sugar and grain nonstructural carbohydrates. Crop Science, 48, 2165-2179. doi:10.2135/cropsci2008.01.0016

Parh, D.K., Jordan, D.R., Aitken, E.A.B., Mace, E.S., Jun-ai, P., McIntyre, C.L. and Godwin, I.D. (2008) QTL analysis of ergot resistance in sorghum TAG. Theoretical and Applied Genetics, 117. doi:10.1007/s00122-008-0781-8

Phuong, N., Afolayan, G., Stützel, H., Uptmoor, R. and El-Soda, M. (2018) Unraveling the genetic complexity underlying sorghum response to water availability. PLOSONE (under publication).

Rajkumar, F.B., Kavil, S.P., Girma, Y., Arun, S.S., Dadakhalandar, D., Gurusiddesh, B.H., Patil, A.M., Thudi, M., Bhairappanavar, S.B., Narayana, Y.D., Krishnaraj, P.U., Khadi, B.M. and Kamatar, M.Y. (2013) Molecular mapping of genomic regions harbouring QTLs for root and yield traits in sorghum (Sorghum bicolor L. Moench). Physiology and Molecular Biology of Plants, 19, 409-419. doi:10.1007/s12298-013-0188-0

Rami, J.F., Dufour, P., Trouche, G., Fliedel, G., Mestres, C., Davrieux, F., Blanchard, P. and Hamon, P. (1998) Quantitative trait loci for grain quality, productivity, morphological and agronomical traits in sorghum (Sorghum bicolor L. Moench).
Theoretical and Applied Genetics, 97, 605-616. doi:10.1007/s 001220050936

Reddy, R., Reddy, N., Madhusudhana, R., Murali, Mohan S., Seetharama, N. and Jagannatha, Vishnu P. (2014) Detection and validation of stay-green QTL in post-rainy sorghum involving widely adapted cultivar, M35-1 and a popular staygreen genotype B35. BMC Genomics, 15, 1-16. doi:10.1186/1471-2164-15-909

Rose, M.R. (1982) Antagonistic pleiotropy, dominance, and genetic variation1. Heredity, 48, 63-78.

Shiringani, A.L., Frisch, M. and Friedt, W. (2010) Genetic mapping of QTLs for sugar-related traits in a RIL population of Sorghum bicolor L. Moench. Theoretical and Applied Genetics, 121, 323-336. doi:10.1007/s00122-010-1312-y

Srinivas, G., Satish, K., Madhusudhana, R., Nagaraja, Reddy, R., Murali, Mohan S. and Seetharama, N. (2009) Identification of quantitative trait loci for agronomically important traits and their association with genic-microsatellite markers in sorghum. Theoretical and Applied Genetics, 118,1439-1454. doi:10.1007/s00122-009-0993-6

Xin, Z., Li Wang, M., Barkley, N.A., Burow, G., Franks, C., Pederson, G. and Burke, J. (2008) Applying genotyping (TILLING) and phenotyping analyses to elucidate gene function in a chemically induced sorghum mutant population BMC. Plant Biology, 8, 103 doi:10.1186/1471-2229-8-103

Zou, G., Zhai, G., Feng, Q., Yan, S., Wang, A., Zhao, Q., Shao, J., Zhang, Z., Zou, J. and Han, B. (2012) Identification of QTLs for eight agronomically important traits using an ultra-high-density map based on SNPs generated from high-throughput sequencing in sorghum under contrasting photoperiods. Journal of Experimental Botany, 63. doi:10.1093/jxb/ers205

(Received 3/10/2018; accepted 18/11/2018) 


\section{تحديد ال QTLs المرتبطة بالمحصول والصفات المرتبطة به في الذرة الرفيعة}

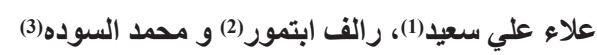

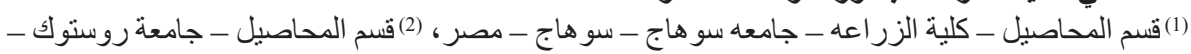

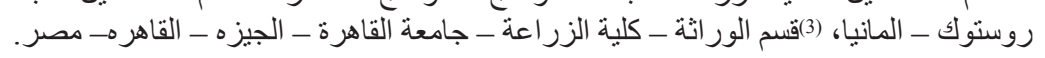

\footnotetext{
يعتبر محصول الحبوب و الصفات المرتبطه به كمو عد طرد السنابل ووزن المائة حبة و عدد حبوب النبات و

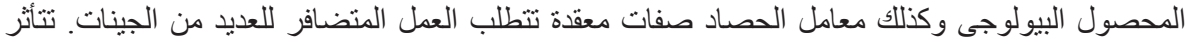

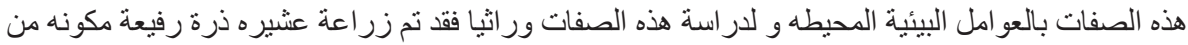

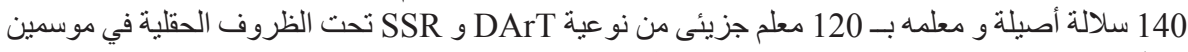
متتاليين 2016/2015 و 2017/2016 في محافظة سو هاج - مصر.

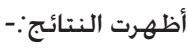
1. ت تفاعلًا مهمًا بين التر اكيب الور اثيه ومن ثم المعلمات الجزيئية المرتبطة بالصفات موضع الدراسه ومواسم 2. تم رصد 13 مقطع جزيئى مرتبطه بالصفات موضع الدراسة حيث أرتبطت اربعة مقاطع جزيئيه بالصفات المدروسه فى الموسم الثانى فقط دون الموسم الأول.

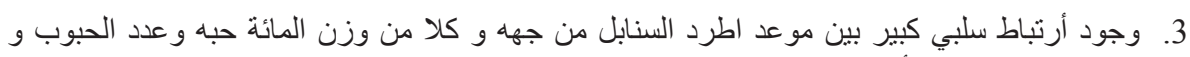

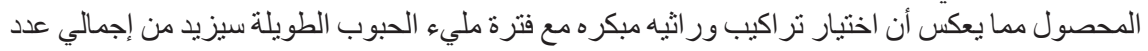

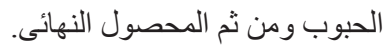

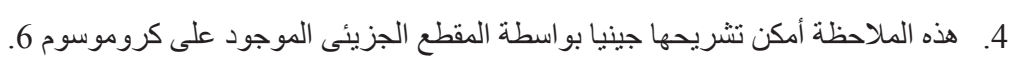

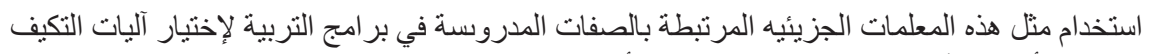
المو اتية يمكن أن يساعدً بالوفاء بالمتطلبات الغذائية لأعداد البشر المتز ايدة.
} 